Received 13.07.2016 Reviewed 24.08.2016 Accepted 21.09.2016

A - study design

B - data collection

C - statistical analysis

D - data interpretation

$\mathbf{E}$ - manuscript preparation

F - literature search

\section{Range of soil and climate characteristics appropriate for Pistacia atlantica forest development and rehabilitation (case study: Fars province, Iran)}

\author{
Masoud NEJABAT ${ }^{\text {ABCDEF } ₫}{ }^{\text {, Mohammadreza NEGAHDARSABER }}{ }^{\text {ABF }}$, \\ Gholamreza GHAHARI ${ }^{\mathrm{BCD}}$
}

Soil Conservation and Watershed Management Department, Fars Research and Education Center for Agriculture and Natural Resources, AREEO, Shiraz, Iran; e-mail: m.nejabat@areo.ir, m.negahdarsaber@areo.ir, gh.ghahri@areo.ir

For citation: Nejabat M., Negahdarsaber M., Ghahari G. 2017. Range of soil and climate characteristics appropriate for Pistacia atlantica forest development and rehabilitation (case study: Fars province, Iran). Journal of Water and Land Development. No. 32 p. 71-78. DOI: 10.1515/jwld-2017-0008.

\begin{abstract}
Investigation of ranges of soil and climate characteristics appropriate for the tolerant species: Pistacia atlantica subsp. mutica according to field study was the main objective of this research. This study was carried out based on random sampling across $20 \times 20 \mathrm{~km}$ wild pistachio forests of Fars province (Iran). Results showed that mountainous and hilly lands are the main land types that pistachio species have evolved on. Statistical analysis of physical and chemical soil characteristics based on principal component analysis (PCA) method showed that wide ranges in soil characteristics, even up to about $40 \%$ differentiation in some measured properties, did not restricts this subspecies natural growth. The main growth limiting factors were shallow soil depth and light soil texture that decreased storage capacity of soil moisture, necessary for wild pistachios survival during drought and long dry periods. Climatic elements were analysed through the same approach and showed that temperature, precipitation and wind with overall variability of $85.9 \%$ were the most effectual factors. Pistacia atlantica subsp. mutica is one of the species refractory to various soil conditions and adapted to weak soils for the establishment and rehabilitation of forests in semi-arid regions.
\end{abstract}

Key words: climatic elements, drought, forest soils, principal component analysis (PCA), semi-arid regions, soil physical and chemical properties

\section{INTRODUCTION}

Wild pistachio forests are distributed in some parts of semi-arid zone at Eurasia plateau. This type of forest with Pistacia atlantica species is observed and reported from Northern Africa (Western Sahara, Morocco and Tunisia), Eastern Europe (Macedonia and Greece) Anatolian plateau (Turkey), Zagros plateau (Iran) and Hindu Kush plateau (Afghanistan and Pakistan) [BAHRANI et al. 2010]. Zagros growth regime is one of the most important forest lands in Iran and wild pistachio (Pistacia atlantica subsp.mutica) is main plant species in this area, which grows at the altitude between 1000 to $2300 \mathrm{~m}$ a.s.l. Deforestation for overuse logging and changing land use has been altered that they are in the danger of total destruction [ALIOWLAD et al. 2007].

Fars province, located in southern part of Zagros Mountains, is the main habitat for Pistacia atlantica which is disseminated over than 1,200,000 hectares of lands. The habitats of Pistacia atlantica are spread out in two third of the central and northern parts of Fars province and can be mainly found in cold semi-arid, intermediate desert and intermediate semi-arid climate 
conditions [AMIRI 1999]. There are four pistachio forest types in this region including pistachio atlantica; pistachio-acer; pistachio-almond and pistachio-oak. These wild pistachios are of different varieties which have been greatly affected by climatic, geomorphologic and pedological factors [NEGAHDARSABER, FATTAHI 2003].

Wild pistachio species are also grown in Irano-Turani region that has low rainfall and the length of dry seasons has significantly separated this area from other regions. Heat variation is high in such regions and this is the reason life activities of plants have been reduced due to cold and freezing winters and long dry summers. This area (Irano-Turani region) has covered three fourth of Iran lands and More than 300 different types of trees and shrubs are found in this area [SABETI 1993]. Climate can directly or indirectly affects environmental factors those influences on growth of plants [YAGHMAIE et al. 2008]. Experiments conducted in recent decades indicate the whether condition has potential to control the distribution of plant species [MORRISON, MORECROFT 2006]. Wild pistachio is a xerophyte plant and dominant species which covers South-West Asia and North-Africa at margin of desert to Mediterranean climate [MONTAZERI et al. 2014]. WALKER et al. [1987] study showed that wild pistachio is one of the resistant species to adverse environmental conditions such as different climates (arid, semi-arid and sub-humid).

The altitude at which Pistacia atlantica can be grown is variable in different parts of the world. ZOHARY [1995] states that altitude of 900-3000 m a.s.l. is suitable for the growth of these types of plants in Iran. Combination of wild pistachios distribution map and hypsometric maps through geographic information system of Fars province indicated $57 \%$ of these bed growths are located in 1000-2000 $\mathrm{m}$ a.s.l. [NEGAHDARSABER et al. 2009]. This study also re- vealed that, $25.5 \%$ of these forests are located on $15-$ $30 \%$ slope and $66 \%$ of the geographical direction of such plantations is towards the north.

A severe decrease in vegetation cover of Fars province because of the drought it has faced in the last couple of years, has led to increased soil erosion in this region. Due to the loss of forest vegetation, Pistacia atlantica and oak forests in particular, furnishing the necessary conditions for the recovery of these species is required. In order to retrieval these forests baseline, updated information on desire ecological conditions needs to be obtained. The objective of this study was to find relationships between climate and soil characteristics on wild pistachio natural growth in the Fars province and identifying the main limiting factors.

\section{MATERIAL AND METHODS}

The study area is located in the southern part of the Irano-Turani growth region (in southern part of Iran), and occupied over $124,000 \mathrm{~km}^{2}$ of Fars province (Iran) at $50^{\circ} 37^{\prime}$ to $55^{\circ} 40^{\prime}$ east longitude and $27^{\circ} 7^{\prime}$ to $31^{\circ} 45^{\prime}$ north latitude with average elevation of $1491 \mathrm{~m}$ a.s.l. (Fig. 1). Investigation of soil status (the current situation of this type of forest soil) was designed according to analysis of sampled soils. To locate sampling sites, digital maps of wild pistachio forest of Fars province at scale of 1:250 000 were obtained. Selecting a geographic vertical grid (Universal Transfer Mercator (UTM) coordinates) based on habitat of Pistacia atlantica (pistachio distribution map of Fars province) intersection with $20 \times 20 \mathrm{~km}$ network was the next step (Fig. 2). After finding the corresponding point in the field, an area with $2000 \mathrm{~m}^{2}$ was investigated. The general and specific characteristics of land, forest type and land geomorphology was reported and soil sampling was carried out.

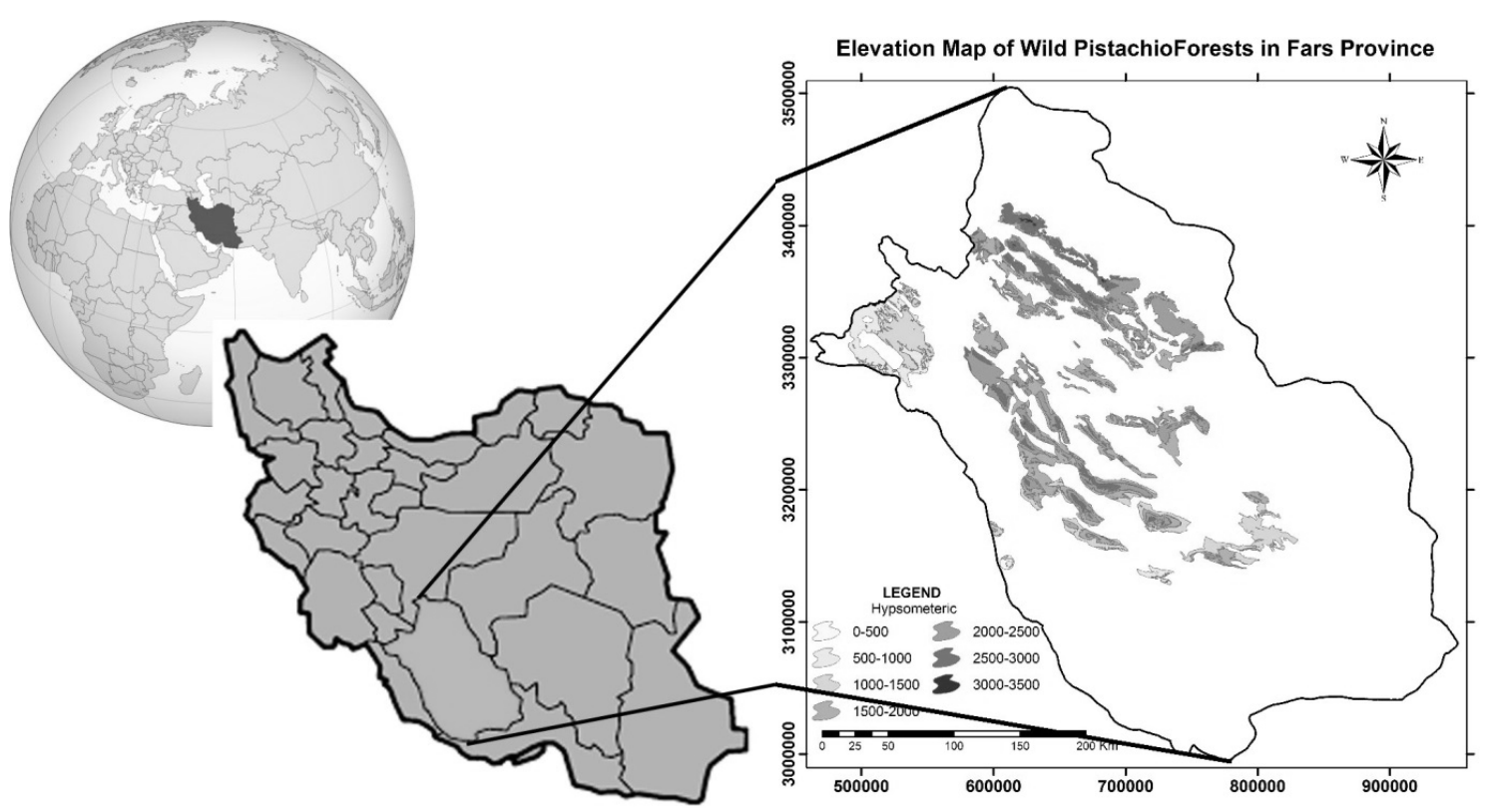

Fig. 1. Location and elevation ranges of Fars Province; source: own elaboration 
Soils were sampled in the canopy shadow of Pistacia atlantica trees based on the criteria that the effective soil depths should be $30 \mathrm{~cm}$ [BROWN 1999; HosSEINI et al. 2012]. The sampled soils taken from field for physio-chemical analysis were delivered to the laboratory.

Soils texture (percent of sand, silt and clay) were identified by GEE and BAUDER [1986] method. To determine the percentage of organic carbon and soil organic matter, dichromate oxidation method was used [NELSON, SOMNERS 1996]. Calcium carbonate equivalent percentage and bicarbonate concentrations were measured and reported using acid neutralization method [LEOPPERT, SUAREZ 1996]. Salinity based on electrical conductivity defined by RHOADES [1996] method. The statistical study of the soil experimental results was carried out based on principal component analysis (PCA) that can synthesize environmental data according to their matrix [KENT, COKER 2001]. These statistical analyses were performed in Minitab software.

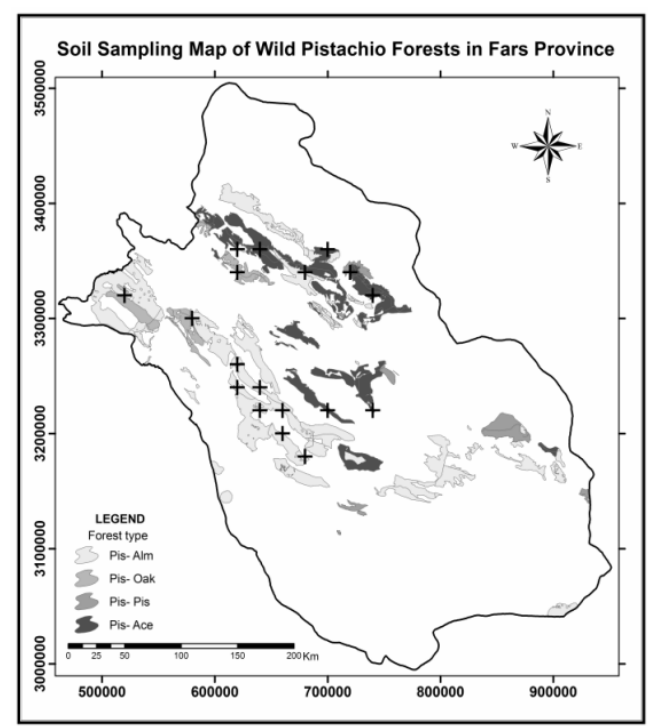

Fig. 2. Map of natural growth fields for Pistacia atlantica, accompanying species, and sampling points

in Fars Province (20-km grids); source: own elaboration

\section{RESULTS}

Field studies of the sites covering about three percent of Fars wild pistachio forest area, showed that soil erosion and land degradation of these regions are moderate to high. Based on the geomorphological studies most of these sites are located on lands with high to moderate slope and shallow soil depth. Settlements elevations of wild pistachio were found to be at 500 to $2000 \mathrm{~m}$ a.s.1. (Fig. 1). The study sites near villages, residential areas and the safe passage of nomads in pasture and shrubs were poor condition and wild pistachio trees per unit area was low (Photo 1).

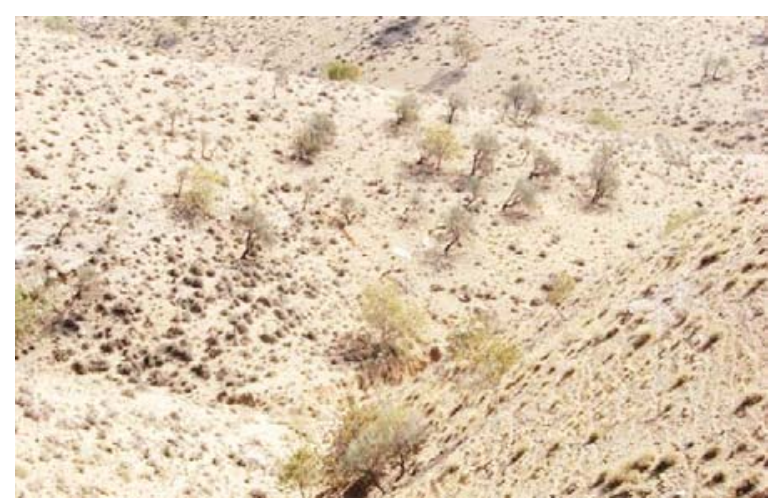

Photo 1. A general view from the studied area near Morgh village (phot. M. Nejabat)

During the absent of more detail maps, land resources (land types) and land units (land units) was distinct from field observations. According to integration land recourses map with Pistacia atlantica distribution map, the presence of this species was observed in almost all of the land units. Based on land type, different habitat of Pistacia atlantica were divided into four main groups: mountainous lands, hilly lands, trace lands and debris coin. According to field studies the general description of sites (chosen clusters) are presented in Table 1. Generally, the density of range covers, shrubs and Pistacia atlantica is low in land with lower slopes (less than 10\%), compared to higher slop (more than $40 \%$ ). This is due to easier access for animals grazing, destroying the bushes, and harvesting hardwood for fuel.

Soil depth in most of these lands is low (less than $30 \mathrm{~cm}$ ) and soil surface is gravelly (more than $35 \%$ of components is formed by pebbles, gravels and boulders). Mountainous and hilly lands include rocks (about 30\% out cropped rocks) can be easily seen. Due to poor vegetation and initial stage of soil formation and shortage of organic matter, soils structures are week and severe water erosion can be observed in most of the study areas.

Table 1. Typical measured environmental characteristics in the study regions

\begin{tabular}{|l|c|c|l|l|c|l|l|}
\hline Cluster name & $\begin{array}{c}\text { Eastern } \\
\text { longitude }\end{array}$ & $\begin{array}{c}\text { Northern } \\
\text { latitude }\end{array}$ & \multicolumn{1}{|c|}{ Land type } & Origin & $\begin{array}{c}\text { Soil } \\
\text { depth }\end{array}$ & \multicolumn{1}{|c|}{ Stone and gravel type } \\
\hline Sarpaniran & $53^{\circ} 29^{\prime} 16^{\prime \prime}$ & $29^{\circ} 59^{\prime} 15^{\prime}$, & $\begin{array}{l}\text { alluvial plain and } \\
\text { terrestrial area }\end{array}$ & $\begin{array}{l}\text { Dolomite and } \\
\text { gypsum }\end{array}$ & low & $\begin{array}{l}\text { more than } 15 \% \text { sound rock and } \\
\text { more than } 30 \% \text { gravel }\end{array}$ & medium \\
\hline Sivand dam & $52^{\circ} 52^{\prime} 10^{\prime \prime}$ & $30^{\circ} 10^{\prime} 4^{\prime \prime}$ & $\begin{array}{l}\text { mountainous leading } \\
\text { to low plain areas }\end{array}$ & Dolomite & $\begin{array}{l}\text { very } \\
\text { low }\end{array}$ & $\begin{array}{l}\text { more than } 30 \% \text { sound rock, more } \\
\text { than } 10 \% \text { outcrop }\end{array}$ \\
\hline $\begin{array}{l}\text { Meimand due to } \\
\text { water flow }\end{array}$ \\
road
\end{tabular}

Source: own study. 
Asmari and Jahrom Asmari which are the dominating geological formations in this region causes calcareous soil (generates from calcareous parent material) in all of specimens. Weak reaction of soils to 0.1 normal choleric acid shows the low bicarbonate and poor amount or nonexistence of gypsum in the soils. A typical view of Pistacia atlantica growth, distribution, and land resources in the studied forest field is shown in Figure 3.

Soil physical and chemical analysis showed that loam or medium is dominant soil texture type and organic matter percentage is very low $(0.3 \%$ to $0.74 \%$ ). The acidity of saturated soils is around neutral (7.25-7.54) that is consequence of high Equiva- lent Calcium Carbonate (31.7-40.2). Saline soil is not observed in any places of study area and concentration of Bicarbonate is less than $0.35 \mathrm{meq} \cdot(100 \mathrm{~g})^{-1}$ (Tab. 2).

The statistical analyses of these results according to PCA method [KENT, COKER 2001] are showed in Table 3 and Figure 3. Application of PCA for statistical analysis on soil data results showed after three initial steps, Eigenvalue went to less than 1 and in first 4 steps; cumulative proportion was $92 \%$ as shown in Table 3. The results of PC1 (greatest and main proportion percentage), soil texture (sand, silt and clay) and salinity have the most diffraction and saturation percentage have the least diffraction.

Table 2. Physico-chemical characteristics of studied soil specimens

\begin{tabular}{|c|c|c|c|c|c|c|c|c|c|c|c|}
\hline \multirow[b]{2}{*}{$\begin{array}{c}\text { Location } \\
\text { (Cluster name) }\end{array}$} & \multicolumn{3}{|c|}{ Percent soil content } & \multirow[b]{2}{*}{ 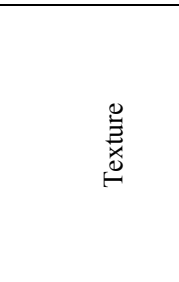 } & \multirow{2}{*}{ 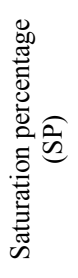 } & \multirow{2}{*}{ 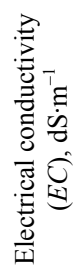 } & \multirow{2}{*}{ 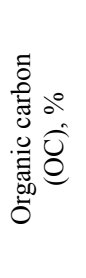 } & \multirow{2}{*}{ 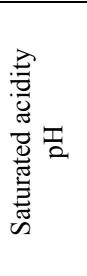 } & \multirow[b]{2}{*}{ 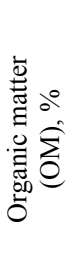 } & \multirow{2}{*}{ 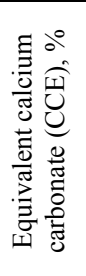 } & \multirow{2}{*}{ 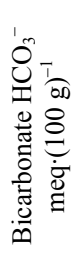 } \\
\hline & 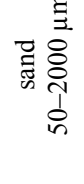 & 党害 & 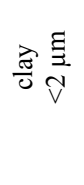 & & & & & & & & \\
\hline Sarpaniran & 52.56 & 26 & 21.44 & silty clay loam & 54.7 & 1.05 & 0.32 & 7.46 & 0.55 & 32.4 & 0.19 \\
\hline Sivand dam & 62.56 & 24 & 13.44 & silty loam & 47.2 & 2.86 & 0.49 & 7.59 & 0.84 & 28.7 & 0.34 \\
\hline Morghvilage & 62.56 & 26 & 11.44 & silty loam & 42.8 & 1.83 & 0.58 & 7.31 & 1.00 & 26.9 & 0.16 \\
\hline Ghaderabad & 58.56 & 30 & 11.44 & silty loam & 45.2 & 1.96 & 0.43 & 7.54 & 0.74 & 34.8 & 0.18 \\
\hline Chenaroo & 46.56 & 26 & 27.44 & clay loam & 50.3 & 0.97 & 0.24 & 7.37 & 0.41 & 36.1 & 0.10 \\
\hline Mamoo & 48.56 & 25 & 26.44 & loam & 48.1 & 0.91 & 0.36 & 7.32 & 0.63 & 38.5 & 0.13 \\
\hline Mahjan & 44.56 & 34 & 21.44 & loam & 44.2 & 1.23 & 0.27 & 7.46 & 0.48 & 32.9 & 0.20 \\
\hline Khaniman & 46.56 & 31 & 22.44 & loam & 37.6 & 1.33 & 0.31 & 7.39 & 0.54 & 31.7 & 0.20 \\
\hline Bakan & 40.56 & 29 & 30.44 & clay loam & 50.3 & 0.83 & 0.17 & 7.25 & 0.30 & 40.2 & 0.18 \\
\hline Honeifaghan & 60.56 & 22 & 17.44 & silty loam & 31.8 & 0.59 & 0.24 & 7.32 & 0.42 & 27.4 & 0.12 \\
\hline Maximum & 62.56 & 34 & 30.44 & clay loam & 54.7 & 1.96 & 0.43 & 7.54 & 1.00 & 40.2 & 0.20 \\
\hline Minimum & 40.56 & 25 & 11.44 & loam & 37.6 & 0.83 & 0.17 & 7.25 & 0.30 & 31.7 & 0.10 \\
\hline Variation, $\%$ & 64.83 & 73.53 & 37.58 & - & 68.74 & 42.35 & 39.53 & 96.15 & 30 & 78.86 & 50 \\
\hline
\end{tabular}

Source: own study.

Table 3. Summation coefficient of principal component analysis based on correlation matrix

\begin{tabular}{|l|c|c|c|c|}
\hline \multicolumn{1}{|c|}{ Variable } & PC1 & PC2 & PC3 & PC4 \\
\hline Sand & 0.412 & 0.270 & -0.194 & 0.023 \\
\hline Silt & -0.115 & -0.402 & 0.682 & 0.435 \\
\hline Clay & -0.434 & -0.110 & -0.132 & -0.261 \\
\hline SP & -0.106 & -0.476 & -0.618 & 0.177 \\
\hline EC & 0.398 & -0.309 & -0.040 & 0.059 \\
\hline OC & 0.393 & -0.014 & -0.189 & 0.575 \\
\hline PH & 0.306 & -0.397 & 0.089 & -0.265 \\
\hline $\mathrm{CCE}^{-}$ & -0.356 & -0.321 & -0.215 & 0.208 \\
\hline $\mathrm{HCO}_{3}{ }^{-}$ & 0.289 & -0.414 & 0.075 & -0.513 \\
\hline Eigenvalue & 5.364 & 2.029 & 1.094 & 0.763 \\
\hline Proportion\% & 51.2 & 22.6 & 11.7 & 6.6 \\
\hline Cumulative\% & 51.2 & 73.8 & 85.5 & 92 \\
\hline
\end{tabular}

Source: own study.

Results of using principal component analysis on 26 climatic elements of Fars province showed, 4 main component cover more than $89 \%$ of cumulative proportion (Tab. 4) and eigenvalue of remained elements are less than one those deleted from more statistical analysis. Precipitation, temperature and wind make more than $85 \%$ proportion of climatic elements. Results of crossing map of wild pistachio forest of Fars province (Fig. 2) and corresponding cells of those three elements for determining of the mean score of the three components is shown in Table 5.

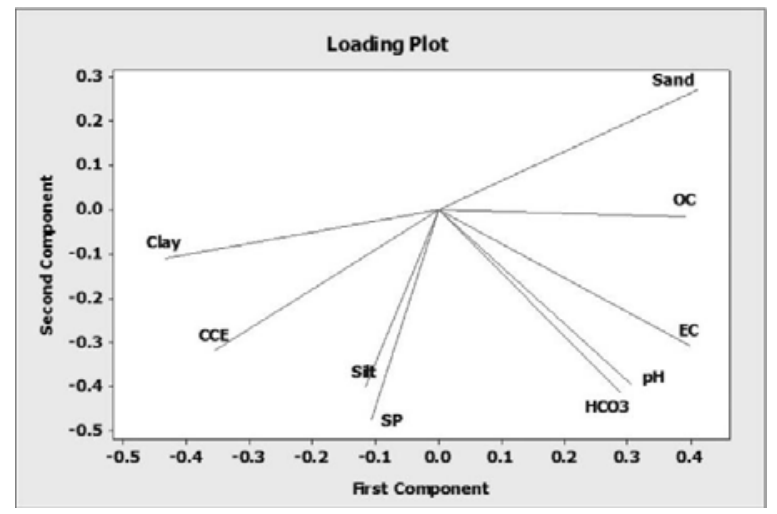

Fig. 3. Diagram of loading plot based on soils physical and chemical properties; source: own study 
Table 4. The relative importance of climatic elements

\begin{tabular}{|l|c|c|c|c|}
\hline \multicolumn{1}{|c|}{ Parameter } & PC1 & PC2 & PC3 & PC4 \\
\hline Eigenvalue & 3.657 & 2.774 & 1.116 & 0.933 \\
\hline Proportion\% & 51.5 & 29.6 & 4.8 & 3.3 \\
\hline Cumulative\% & 51.5 & 81.1 & 85.9 & 89.2 \\
\hline
\end{tabular}

Source: own study.

Table 5. The most effective climatic elements range for wild pistachio

\begin{tabular}{|c|c|c|c|c|c|c|}
\hline \multirow[t]{2}{*}{$\frac{\mathscr{g}}{\stackrel{\pi}{\supset}}$} & 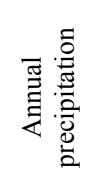 & 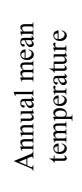 & 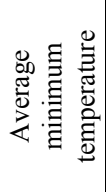 & 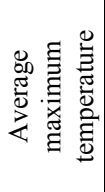 & 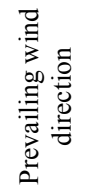 & 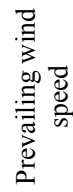 \\
\hline & $\mathrm{mm}$ & \multicolumn{3}{|c|}{${ }^{\circ} \mathrm{C}$} & degree & Not \\
\hline Max & 695.50 & 25.98 & 17.68 & 33.42 & 317.98 & 10.31 \\
\hline Min & 180.45 & 13.82 & 6.31 & 20.20 & 138.85 & 6.66 \\
\hline Average & 340.16 & 19.92 & 12.35 & 26.85 & 274.01 & 7.80 \\
\hline
\end{tabular}

Source: own study.

\section{DISCUSSION AND CONCLUSIONS}

Results of the field study revealed a higher density of wild pistachio trees on gradient lands, especially land types such as: mountain, hilly and piedmont plains, because stakeholder's accessibility in these lands is not easy. A study in western Zagros (Kermanshah province) also showed higher presence of these species trees on the hilly areas, mountainous and high slop pediments [BAHRANI et al. 2010].

Shallow depth of the soil which is caused by the sever soil erosion in the last couple of decades is the main land limiting factor that reduces the regeneration of this species. Shallow soils with light texture also limits the moisture storage (from rain) necessary for wild pistachio survival during drought and long dry periods. Due to poor vegetation cover, initial stage of soil formation and hence low organic matter, soil structure is week (low soil aggregation and high soil erodibility) and severe water erosion was observed in most of the study areas. Results of REZAEYAN et al. [2009] research also presented same conditions in most of Zagros Mountains that causes weakness of soil structure and decreases erosion resistance. SALEHI et al. [2008] and Le Polain DE WAROUX, LAMBIN [2012] also believe that deforestation in Zagros region or semi-arid forests always proceed to land degradations, so conservation of one protects another. SHEKARCHIAN, ESFANDIARPOUR [2006] studies showed that due to decrease in the trees density in arid and semi-arid regions of Zagros forests, soil erosion increased significantly. ZANGANEH [2001], who conducted such a study in Ghalajeh (Kermanshah province), also indicated that Pistacia atl antica has a better chance of growth with higher quality in the northern slopes of this region than the southern slopes.

According to SALEHI et al. [2005] and MAHMOUDI et al. [2005], physical and chemical properties of soil are the most important factor that affected wild pistachio growth. Therefore, the natural presence of Pistacia atlantica in these regions insists the appropriateness of the chemical and physical conditions and geomorphological situation. SCHOENHOLTZ et al. [2000] emphasized that the natural growth deficiency followed the undesired interaction between plants and the soil physico-chemical properties. Furthermore, based on BINKLEY and GIARDINA's [1998] finding similar soil test results, despite the difference in their locations, shows their vulnerability towards the growth of a particular species of tree that is compatible with ecological conditions.

The cluster analysis showed that the percentage of clay, sand and saturation percentage (SP) have high variety. TAHERI ABKENAR et al. [2013] studies also did not indicate significant differences among samples soil texture and saturation percentage in Khojir wild pistachio national park. LIMANE et al. [2014] research confirmed large difference in soil texture of wild pistachio forest in Algeria.

Most of wild pistachio species are tolerant to soil salinity and keep natural growth and development [SEPASKHAH, KARIMI-GOGHARY 2003], but ECe of sampled soils are low too. The percentage of equivalent calcium carbonate (CCE) tolerance (due to the calcareous parent materials of most soil samples) is high $(8.5 \%)$ and also, high buffering capacity of the soils (causes from lime presence) leaded $\mathrm{pH}$ close to neutral, with little change. TAHERI ABKENAR et al. [2013] studies confirmed a wide range of variety in these three factors in the wild pistachio forest.

Cluster analysis (CA) showed that Chenaroo and Mamoo regions have the most similarity level (96.47\%) and the least distance (1.87) from each other. On the other hand, the minimum similarity and maximum distance of soil properties occurred in Sivand Dam's region (Fig. 4). The salinity and bicarbonate concentration are the main cause of this difference. Measured characteristics of the soil samples in this study did not have any overlap with the ecological limits explained by ZANGENEH [2001]. Even so, $\mathrm{CA}$ and PCA statistical procedures indicate that about $40 \%$ of the variations in soil characteristics do not impose any specific restrictions for this species.

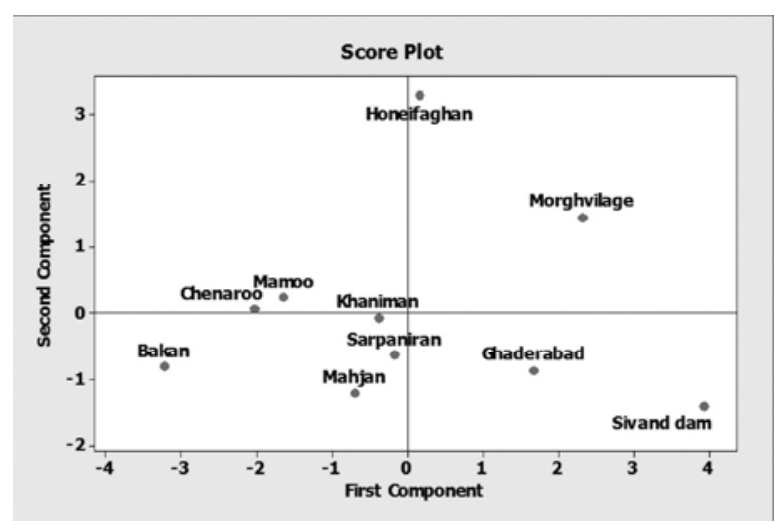

Fig. 4. Cluster analysis for soil mean characteristics; source: own study 
The main limiting factor in natural growth of wild pistachio is shortage of soil moisture storage from rain. OWLIAIE [2010] studies presented the influence of semi-arid climate on forest ecosystems (southern part of Zagros pistachio forests in) is more important than soil chemical and physical conditions. GHOLAMI et al. [2007] studies indicate that low soil depth and sandy soil texture are inappropriate $\mathrm{n}$ for wild pistachio natural growth. BODAGHI [1995] believes that the most important factors for poor natural development of wild pistachio in protected Zagros region is the shortage of soil water content.

The three climatic components (temperature, precipitation and wind) are the most important factors those lead the behaviour of the climate in the study areas. HATAMI BAHMAN BIGLU, KHOSHAL DASTJERDI [2010] studies according to application of principal component analysis on 25 whether elements showed, four climatic factors in Fars province are the most influence. Their results showed that the four components (temperature, precipitation, wind and summer precipitation mechanism) are the main factors regionalized Fars province. The PCA results showed the annual precipitation is the most important climatic element affecting distribution of wild pistachio and the temperature with the lowest value (the biggest negative effects) indicates sensitivity of wild pistachio to temperature rise. ROSTAMIKIA et al. [2010] investigation in Ardabil province (Khalkhal forest) showed the temperature is the main limiting factor in whether elements in wild pistachio lodgement.

Inappropriate changes in Landuse at the Zagros zone of Fars province such their use as gardens, miss management in wood harvesting, excessive grazing by livestock, and poor soil and water conservation operations, are the most significant factors that have led to the deterioration and degradation of wild pistachios in these areas. Soil conservation and watershed management projects can improve condition to rehabilitate and develop wild pistachio forest even in a semi-arid region as Fars province.

\section{ACKNOWLEDGEMENTS}

This article authors are thankful to Mr. Ali Abbasi for his cooperation in field data collection and Mrs. Laden Jowkar for valuable advice on the statistical analysis of this study. This research was performed with support of Fars Research and Education Center for Agriculture and Natural Resources that made us so appreciate for their accompanying.

\section{REFERENCES}

Aliowlad J., Najafifar A., Seiavoshi K. 2007. Soil survey and land capability evaluation of Zardalan Shirvan Chardavol region, Ilam Province. Abstracts of the 10th Iran soil congress. Karaj, Iran: Tehran University, 2628 August 2007 pp. 742. (In Persian with an abstract in English).

AMIRI A. 1999. Investigation of Zagros forest ecosystem in Lordegan, Chaharmahal and Bakhtiari province. Msc thesis. Tarbiat Modares University Press pp. 113. (In Persian).
Bahrani M.J., Yeganeh M., Heidari B. 2010. Distribution of Pistacia mutica F. and M. as influenced by topographical factors and soil properties in mountain areas of western Iran. International Journal of Ecology and Environmental Science. Vol. 36 p. 27-37.

BinKLEY D., GiARDinA C. 1998. Why do tree species affect soils? The warp and whoop of tree-soil interaction. Biogeochemistry. Vol. 42 p. 89-106.

BODAGHI A. 1995. Investigation of regeneration, distribution and ecological condition of wild pistachio. Proceeding of the first national seminar of wild pistachio. Ilam University, Iran. 4-5 November 1995 p. 472-481. (In Persian with an abstract in English).

BROWN K.J. 1999. Soil sampling and sample handling for chemical analysis. In: Soil analysis: An interpretation manual. Eds. K.I. Peverill, L.A. Sparrow, D.J. Reuter. Melbourne. CSIRO Publishing p. 35-54.

Gee G.W., Bauder J.W. 1986. Particle-size analysis. In: Methods of soil analysis. P. 1. Physical and mineralogical methods. 2nd ed. Ed. A. Klute. SSSA Book. Ser. 5.1. Madison. SSSA, ASA p. 383-411.

Gholami S., Hosseini S.M., SAYAdE. 2007. Effect of soil, sowing depth and sowing date on growth and survival of Pistacia atlantica seedlings. Pakistan Journal of Biological Science. Vol. 10. Iss.2 p. 245-249.

Hatami Bahman Biglu H., Khoshal Dastjerdi J. 2010. Application of factor analysis for regionalization of Fars province. Journal of Geographical Space. Vol. 32 p. 48 36. (In Persian with an abstract in English).

Hosseini V., Akhavan R., Tahmasebi M. 2012. Effect of pistachio (Pistacia atlantica) canopy on the spatial distribution of soil chemical characteristics (Case study: Sarvabad, Kurdistan). Iranian Journal of Forest. Vol. 4 p. 13-24. (In Persian with an abstract in English).

KENT M., COKER P. 2001. Vegetation description and analysis. Chichester, Sussex. John Wiley and Sons. ISBN 9780471948100 pp. 363.

Le Polainde WarouX Y., Lambin E.F. 2012. Monitoring degradation in arid and semi-arid forests and woodlands: The case of the argan woodlands (Morocco). Applied Geography. Vol. 32. Iss. 2 p. 777-786.

LEOPPERT R.H., SUAREZ D.L. 1996. Carbonate and gypsum. In: Methods of soil analysis. P. 3. Chemical methods. Eds. D.L. Sparks, A.L. Page, P.A. Helmke, R.H. Loeppert. SSSA Book. Ser. 5.3. Madison SSSA, ASA p. 1264-1279.

Limane A., Smail-SaAdoun N., Belkebir-Boukais A., Kissoum-HAMDINI I. K. 2014. Root architecture adaptation of Pistacia atlantica subsp. atlantica according to an increasing climatic and edaphic gradient: case of a north-south transect in Algeria. Turkish Journal of Botany. Vol. 38 p. 536-549.

MAHMoudi J., ZAHEdi GH., AMIRI A., Adeli A., RAHMANI R. 2005. An acquaintance with the relationship between plant ecological groups and soil characteristics in $\mathrm{Ke}-$ larabad plain forest (Chahloos). Iranian Journal of Natural Resources. Vol. 58 p. 351-362. (In Persian with an abstract in English).

Montazeri M., Ghahari G., Negahdarsaber M.R. 2014. Identifying vegetative climate zones in Fars Province with emphasis on the spread of pistachio forests. Journal of Applied Climatology. Vol. 1 p. 73-86. (In Persian with an abstract in English).

Morison J., MORECROFT M.D. 2006. Plant growth and climate change. Oxford. Blackwell Publishing. ISBN 97814051-3192-6 pp. 232. 
Negahdarsaber M.R., FAtTAHi M. 2003.Wild pistachio (Pistacia attlantica) status in Irano-Turani growth regime, case study, Fars Province. Iranian Journal of Forest and Poplar Research. Vol. 10 p. 99-119. (In Persian with an abstract in English).

Negahdarsaber M.R., FAtTAhi M., PAKParVar M., JowKAR L. 2009. Statistical analysis of physiographic conditions of wild pistachio in Fars Province by GIS. Iranian Journal of Forest and Poplar Research. Vol. 16 p $262-$ 273. (In Persian with an abstract in English).

Nelson D.W., Sommers L.E. 1996. Total carbon, organic carbon, and organic matter. In: Methods of soil analysis. P. 3. Chemical methods. Eds. D.L. Sparks, A.L. Page, P.A. Helmke, R.H. Loeppert. SSSA Book. Ser. 5.3. Madison SSSA, ASA p. 1063-1092.

OWLIAIE H. 2010. Physical and chemical properties of soils under some wild pistachio (Pistacia atlantica) canopies in a semi-arid ecosystem, southwestern Iran. In: Geophysical Research Abstracts. Vienna, Austria: EGU General Assembly, 2-7 May 2010 p. 14979.

Rezaeyan S., Pourmajidian M.R., Jalilvand H., PARSAKHOO A. 2009. Growth parameters of Pistacia atlantica under different soil conditions in Iran. African Journal of Plant Science. Vol. 3 p. 184-189.

RHOADES J.D. 1996. Salinity: electrical conductivity and total dissolved solids. In: Methods of soil analysis. P. 3. Chemical methods. Eds. D.L. Sparks, A.L. Page, P.A. Helmke, R.H. Loeppert. SSSA Book. Ser. 5.3. Madison SSSA, ASA p. 1351-1372.

Rostamikia Y., IMANi A.A., FATAhi M., SHARIFIJ. 2010. Sit demands and qualitative characteristics of wild pistachio in Khalkhal forest. Iranian Journal of Forest and Poplar Research. Vol. 38 p. 489-499. (In Persian with an abstract in English).

SABETI H. 1993. Forests, trees, and shrubs of Iran. Yazd. Yazd University Press pp. 360 (In Persian).

SAlehi A., Wilhelmsson E., SöDERBERG U. 2008. Land cover changes in a forested watershed, Southern Zagros, Iran. Land Degradation and Development. Vol. 19 p. $542-553$.

SAlEhi E., ZARINKAFSH M., ZAHEdi M., AMIRI A., MARVI MOHAJER M. 2005. Soil physico-chemical characteris- tics change relation with trees ecological groups in Namkhaneh series, Khyroodkenar forest. Iranian Journal of Natural Resources. Vol. 58 p. 567-578. (In Persian with an abstract in English).

Schoenholtz S.H., VAn Miegroet H., Burger J.A. 2000. A review of chemical and physical properties as indicator of forest soil quality: Challenge and opportunities. Forest Ecology and Management. Vol. 138 p. 335-356.

SEPASKHAH A.R., KARIMI-GOGHARY S.H. 2003.Growth and chemical composition of pistachio affected by salinities and depths of water table. Communication in Soil Science and Plant Analysis. Vol. 34 p. 343-355.

ShEKARChIAN A., EsfandiarPouR P. 2006. Soil survey of wild pistachio forests and its impacts on decreasing soil erosion. In: Proceeding of second national conference on watershed, soil and water resources management. Iran: Kerman University, 22-23 March 2006 p. 638648. (In Persian with an abstract in English).

TAHERI ABKENAR K., SAlEhi A., BAGHERI J., RAVANBAKHSH H. 2013. Some ecological properties of Pistacia atlantica Desf in Khojir National Park of Iran. Chinese Journal of Applied and Environmental Biology. Vol. 19 p. 415-420.

Walker R., Torokfalvy E., Behboudian M.H. 1987. Uptake and distribution of chloride, sodium, and potassium, ions and growth of salt treated pistachio. Australian Journal of Agriculture Research.Vol. 38 p. 383394.

Yaghmaie L., Soltani S, Khodagholi M. 2008. Effect of climatic factors on distribution of Artemisia sieberi and Artemisia aucheri in Isfahan Province using multivariate statistical methods. JWSS - Isfahan University of Technology. Vol. 44 p. 359-370. (In Persian with an abstract in English).

ZANGENEH H. 2001. Ecological demands of pistachio species in Kermanshah province. Iranian Journal of Forest and Poplar Research. Vol. 10 p. 123-130. (In Persian with an abstract in English).

ZoHARY D. 1995.Taxonomy the genus Pistacia L. In: Pistacia genetic resources. International workshop. Palermo, Italy, 29-30 June 1995. Roma. FAO p. 1-11.

\section{Masoud NEJABAT, Mohammadreza NEGAHDARSABER, Gholamreza GHAHARI}

\section{Zakres charakterystyk glebowych i klimatycznych odpowiednich dla rozwoju i rekultywacji lasów Pistacia atlantica na przykładzie prowincji Fars w Iranie}

\section{STRESZCZENIE}

Głównym celem badań terenowych prezentowanych w niniejszej pracy było przeanalizowanie zakresu wartości charakterystyk glebowych i klimatycznych odpowiednich dla podgatunku Pistacia atlantica subsp. mutica. Próby pobierano losowo z poletka w lesie pistacjowym o wymiarach $20 \times 20 \mathrm{~km}$ w prowincji Fars w Iranie. Wyniki dowodzą, że pistacja wyewoluowała na ziemiach górskich i na terenach pagórkowatych. Statystyczna analiza fizycznych i chemicznych właściwości gleb prowadzona metodą składowych głównych (PCA) wykazała, że duża zmienność badanych cech, sięgająca w niektórych przypadkach 40\%, nie ograniczała naturalnego wzrostu badanego podgatunku. Głównymi czynnikami ograniczającymi były płytkie gleby o lekkiej strukturze, które zmniejszały zdolność gleb do zatrzymywania wilgoci niezbędnej dziko rosnącej pistacji do przetrwania długich okresów suszy. Czynniki klimatyczne analizowano tą samą metodą i stwierdzono, że najbardziej istotne były 
temperatura, opady i wiatr o ogólnej zmienności $85,9 \%$. Pistacia atlantica subsp. mutica jest jednym z gatunków najbardziej odpornych na różne warunki glebowe, co może mieć znaczenie dla stabilizowania i rekultywacji lasów na terenach półpustynnych.

Słowa kluczowe: analiza skladowych głównych (PCA), czynniki klimatyczne, fizyczne i chemiczne właściwości gleb, gleby leśne, susza, tereny pótpustynne 